\title{
ECIT 2000 とルーマニア・イアシ工科大学
}

\section{矢鳴 虎夫*}

\section{1.はじめに}

EUFIT 2000 (European Conference on Fuzzy and Intelligent Technology, September 25-29,2000)が、 私のメールに今回の実行委員長の Teodorescu教授か ら流れてきたのは昨年の暮れのことだった，Teodorescu教授は私にBMFSA (Biomedical Fuzzy SystemAssociation, バイオメディカル・ファジイ・シ ステム学会) [1]として、1または2セッションのオーガ ナイズを依頼してきた。たまたま私が今期の BMFSA 会長であることと，7年前、Teodorescu 教授が、九州 工大・飯塚キャンパスにおいて山川烈教授と共同研究 で数ヶ月来学されていた際に，親交を得て以来、今日 までお付き合いさせていただいていることが、今回の オーガナイズを依頼された理由だと思っている.

さて、当初ルーマニアと聞いて、いささか躊躇して しまった，その一方で、東ヨーロッパをいまだ訪問し たことのない私にとってはまたとない機会だけに魅力 でもあった。ついに積極的な教授の呼びかけに応じる べくBMFSAの会員にECIT2000(EUFIT2000から 途中で変更された)への案内用ホームぺージと私の オーガナイズではなし2セッションを構成したい旨の 呼びかけを抗こなった。これを行ったのは、今年2月初 旬で実に 2 㓅上躊躇したことになる。

お陰で、私の分を含めて8件の論文発表の応募があ り、Teodorescu 教授の依頼に応ずることができたの は大変幸いであった。

ところで，今回なぜ ECIT がルーマニアなのか，そ の説明が必要であろう。大会がその土地で開催される ことは、多くの場合、実行委員長の学会での活動や人 格が支配する。今回の場合も, 実行委員長の Teodores$\mathrm{cu}$ 教授の学会活動の積極性とその人格に負うところ 大である。教授は現在，イアシ(IASI) 工科大学・電子 情報工学科の中心的教授であると同時に，南フロリ夕゙ 大学との兼任教授でもある。いつも世界を駆け巡って、 ソフトコンピューティングの啓蒙活動をしておられる。 とりわけファジィカオスの研究では有名である。研究 での活躍ぶりは文献等(例えば[2], [3])で知ることが

* Torao YANARU 九州工業大学工学部電気工学科
出来ても人となりは付合ってみないと分らない。今回、 学会に参加してみて，改めて心くばりのすごさに触れ た．研究室をあげての空港への送迎から、会場に着く なり，昼食のサービスをうけ大いなる歓待に浴した次 第である.

\section{2. 会場について}

さて，会場となったイアシ工科大学の歴史的紹介を 少しさせていただく。

この大学の創立は17世紀にさかのぼり，1634年 Trei Lerarhi 教会付属カレッジとしてスタートしている. 1813年になって, Ghearghe Asachi 氏はルーマニアに おける技術教育機関設立の必要性を思い，その最初の ものとして，イアシに土木工学(Civil Engineering)教 育センターを設立した。これが，現在のイアシ工科大 学としての基盤となった。その後，このセンターは Michaelian Academy $と$ Alexandru Cuza University として発展し，1937年には Polytechnical Institute と なりさまざまな工学分野の大学教育研究機関として発 展し今日に至っている。

Gheorge Asachi 氏の設立に起源をもつこのイアシ 工科大学は，ルーマニアにある49の高等教育の中で最 も古い伝統をもつ権威ある大学である.5年制の学部教 育と6年の修士・博士課程をもつ充実した工科大学・大 学院である $[4]$.

建物はまさに中世ヨーロッパの伝統とアカデミック な風格をそのまま残す重厚なものである。一方で，こ の伝統を維持しながらも，今やロシアの支配から開放 され，旧共産主義を脱皮して21世紀に向けての先端的 工学の教育と研究にも積極的に取り組みはじめている。

\section{ECIT 2000の構成}

\section{1 協蕒機関は:}

INNS(International Neural Network Society), SICC (Italian Society for Chaos and Complexity), BUFSA (Balkan Union for Fuzzy Systems \& A.I.), FLSI (Fuzzy Logic Systems Institute), BMFSA (Biomedical Fuzzy Systems Association) 


\section{2 オーガナイズド機閶は :}

Technical University of Iasi, Faculty of Electronics and Telecommunication. "AI.I. Cuza"University, Faculty of Mathematics and of Informatics.

"Gr.T. Popa" University of Medicine and Pharmacy Iasi, Medical Bioengineering Faculty, Faculty of Economics. "Petro Andrei" University, Iasi, Instutute for Computer Science. Roumanian Academy, Iasi Branch. Roumanian Society for Fuzzy Systems.で構成され，すべてイアシ市内に存在する大 学や学科である。つまり, 古都イアシ市はルーマニア における代表的学園都市である.

\subsection{Honarary Chairman と Co-Chairman は:}

Hans-Jurgen Zimmermann と Abraham Kardel, Horio-Nicolai Teodorescu.で日本ファジイ学会でも よく知られた先生達である.

\section{4 プログラム}

\section{1)9月25日 (大会1日目)：}

5 人の大会企画関係者歓迎挨拶の後, 午前中は, 以下 3人の有名な先生達の招待基調講演がなされた：

Hans-Jurgen Zimmermann "Origins, Present Developments and the Future of Computation Intelligence", Kenneth DeJong "Introduction to Evolutionary Computation and its Applicatio", D. Butnariu "Fazzy Sets;Between Mathematics and Engineering".

午後は 3 人の招待講演を 3 時までに終わり,4時から約 2時間でイアシ市内の各種大学と史跡見学が企画され ていて,歴史的に数百年にわたって干涉国（もしくは地 域)としての苦しみを訴える記念碑に触れた。このよう な体験を持たない私達日本人には，おおよそ真の理解 は出来ないにしても，広い歷史観と世界観をもたなけ ればならないことを痛感した。

2)9月26日 (大会2日目)：

\section{一般講演}

* Mathematics of Fuzzy Set Symposium : 15件

(Romania 6, Austria 1, Italy 6, Greece 2)

* Fuzzy Systems : 5件 (Rom. only)

* Chaos Theory and Applications : 6件

(Romania 5, France 1)

* Special Session organized by BMFSA : 7件

(Japan 7)

* Intelligent Systems in Bio-Medical Applications and Human-Related Sciences：6件 (Rom. only)

* Advanced Computational Techniques for High Speed Frequency Integrated Circuits : 5 件

(Rom. only)

\section{3)9月27日 (3日目)：}

モルドバ地方への1日バスッア(イアシ市から，バス で約3時間)

写真で見られるような静寂な自然を背景にして，美 しい修道院が散在している，教会の壁はキリストをは じめとして名だたる聖人達が描かれており, 質素な美 しさをたたえている．敬虔な新りを捧げている多くの 修道女や一般庶民を目の当たりにして, 近代科学技術 のなかであくせくしている自分達と比較してみたくな る.いったい $21 世$ 紀人間の目指す方向は，20世紀の効 率とスピードを錦の御旗とする価值観の継承であろう か.そうあってはならないことを思いながらも ます ます推進されていくのが現実である。心の平穞を最大 価值として取り込める科学技術は望めないのだろうか. 人間の業の哀しさが想われる基調なツアであった。

ッア終了後, バンケットが始まったのは実に21時か らであった。このあたりの時間的感覚は我々日本人に はとても受け入れ難いものだが、それなりに和気あい あいの懇親会は夜11時まで続いた。私は，この席で， 日本のファジイとりわけBMFSAの宣伝をした。

\section{4)9月28日 (4日目)}

* Image Analysis and Processing : 4件

* Speech and Natural Language Processing : 4件

* Other Applications of Intelligent Systems : 7件

* Demonstrations Session and Exhibition : 6件 (上記21件すべてルーマニアの研究者の発表)

\section{4.おわりに}

以上, ECIT 2000の参加体験記を書かせていただい た. 今回の大会は, ヨーロッパ全体のソフトコンピュー ティングに関する，理論と応用，とりわ汁医療応用人 の動向が聞けるものと期待しての参加だったが、それ は全く期待はずれ，むしろ，ルーマニアの近代化に対 して, ソフトコンピューティングの普及の色合いをも

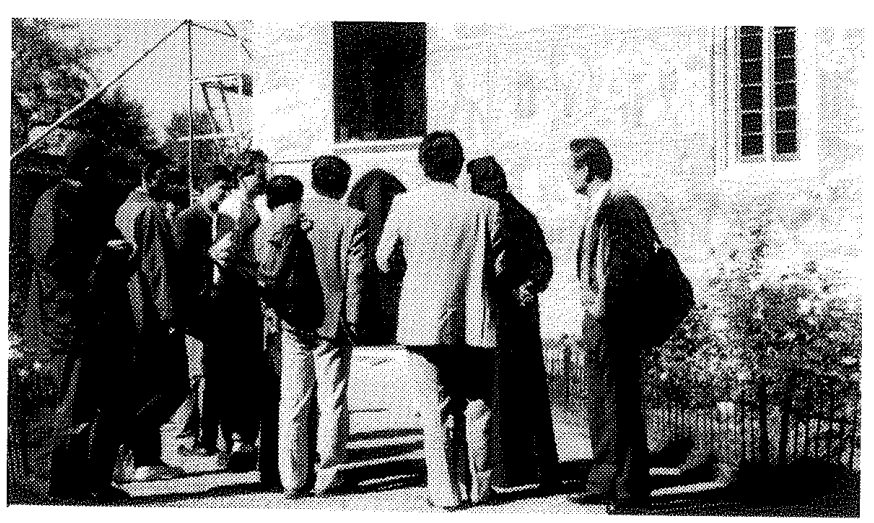

写真 モルドバで修道院を見学する学会参加者達 
つ国際会議だったといえる。昨年，ドイッのアーヘン で行われたEUFIT'99からすれば, ルーマニア大会, 無理していえば(1国の出席者の数は日本人が2番目), ルーマニアと日本のソフトコンピューティングに関す るジョイント学会だったといえよう。それだけに,我々 日本人出席者への暖かい配慮は, とてもマンモス学会 では味わえないものだったことはいうまでもない。こ れからのファジイ・ソフトコンピューティングの国際 学会は，いわゆるIEEEなどが主催するマンモス的国 際会議の推進もさることながら，一方で，開発途上国 での支援的国際会議も21世紀における世界的広がりを 考える上では極めて重要な学会活動と思われる。 最後に，この記事を書かせていただいた，ファジイ 学会の編集委員の方々に厚くお礼申しあげます。
参考文献

[1]BMFSA ホームページ: http : //www.kct.ac.jp/BMFSA/

[2] Horio Nikoli Teodorescu, "Soft Computing Technology in Human-Related Science", CRC Press Ltd. 1999 .

[3] Special Issue devoted to "The European Conference on Intelligent Technologies ECIT2000", International Journal of Chaos Theory and Applications, Vol.5, no.3(2000) T\&T Press Ltd.

[4] The "Gheorghe Asachi" Technical University of Iasi 大学案内

「問い合わせ先」

T804-8550 北九州市戸畑区仙水町1-1

九州工業大学 工学部電気工学科

矢鳴 虎夫

Tel \& Fax : 093-884-3245

Email :yanaru@comp.kyutech.ac.jp 